\section{Intet om meg uten meg!}

Borg M, Kristiansen K, red Medforskning

$\AA$ forske sammen for kunnskap om psykisk helse. 161 s. Oslo: Universitetsforlaget, 2009. Pris NOK 249

ISBN 978-82-15-01431-9

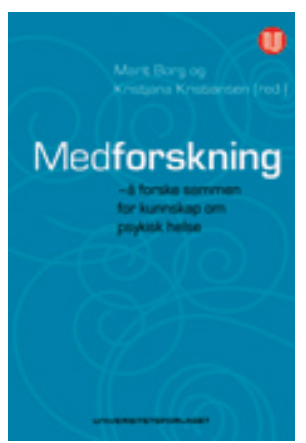

Forfatterne ønsker å formidle innsikt $i$ en ny forskningstradisjon, nemlig medforskning innenfor feltet psykisk helse. Medforskning defineres som forskning med folk istedenfor forskning på eller om folk. Det å invitere

tidligere brukere med i forskningsprosessen blir viktig både med tanke på hvilke forskningsspørsmål som stilles samt presentasjonen og formidlingen av resultatene. Redaktørene, som er erfarne forskere, har samlet en rekke personer, fra inn- og utland, som beskriver hvordan denne forskningen kan bidra til en bedre helsetjeneste og mer nyttig kunnskap for personer med en psykisk lidelse.

Ingen spesiell målgruppe er angitt, man ønsker å nå alle som vil gå i gang med medforskningsprosjekter. Dette med praktiske råd samt dilemmaer og problemstillinger som kan dukke opp i denne forskningsprosessen.

Stoffet er logisk inndelt i to hoveddeler med totalt ti kapitler. Første del tar for seg hva medforskning er og hvordan dette kan tilføre feltet psykisk helse nyttig og viktig kunnskap. Spesielt beskrives det hvordan forskere kan invitere tidligere brukere til forskningsprosjekter og hvordan tokenisme skal unngås. Etiske aspekter ved denne typen forskning blir også omtalt.

Den andre delen tar for seg den mer praktiske gjennomføringen av slike prosjekter. Hvordan tidligere brukere gjennom hele prosessen kan ha en aktiv rolle fra planlegging og innsamling av data til analyseringen og publiseringen av resultatene.

Dette er etter min mening blitt en bok for dem som vil drive med medforskning. Slik fungerer den etter hensikten. En del «tradisjonelle» forskere innen psykisk helse vil nok også kunne finne noen nyttige og tankevekkende råd og synspunkter som de kan bruke i sin videre forskning. Men boken har fått for mye preg av å være et partsinnlegg for en type forskning, nemlig medforskning. Det er aldri noen lur strategi å beskrive negativt annen forskning for å fremheve sine egne metoder. Medforskning kan ha sine positive sider som et supplement til annen forskning, men det i kraft av hva den selv kan frembringe av nyttige resultater. Det er jo ikke slik at forskere (i alle fall ikke kliniske forskere) fortsatt befinner seg i elfenbenstårnet. De prøver vel heller genuint å finne gode, forskbare spørsmål som kan hjelpe pasienter og brukere i både bedrings- og rehabiliteringsprosessen.

Jeg savner også mer konkret hva slags nyttig kunnskap denne metoden har fremskaffet både nasjonalt og internasjonalt. Selv om det er en relativt ny metode, burde det som har vært gjort av forskning vært oppsummert i et eget kapittel. Videre ville nok boken profittert på et kapittel om hva slags forskningsspørsmål medforskningsmetoden kan svare på, som ikke de mer tradisjonelle metodene kan.

Til tross for en del tankevekkende og viktige synspunkter er nok dette blitt en spesialisert bok for forskere som ønsker å komme i gang med medforskning.

\section{Jan Ivar Røssberg}

Regionalt kompetansesenter for tidlig intervensjon ved psykoser - TIPS SørØst Oslo universitetssykehus, Ullevål

\section{Kjærkomen barnebok om kreft}

Handeland AM.

Da pappaen til Johanne hadde kreft

51 s, ill. Sandnes: Kulturhuset Forlag, 2009.

Pris NOK 149

ISBN 978-82-92579-14-5

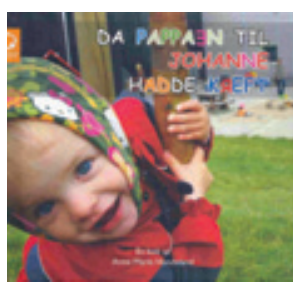

Då far til Johanne fekk kreft, opplevde dei at det var lite litteratur retta mot barn. Denne boka er meint å kunne brukast som eit utgangspunkt når ein skal

snakke med barn om kreft. Første delen vender seg direkte til barna, siste del oppsummerer gode råd til foreldra.

Boka ligg godt $\mathrm{i}$ handa, passe stor til å kunne lesast på senga. Teksten er illustrert med enkle, levande bilete av den vesle familien på tre, der vi følgjer dei gjennom kvardagen både på sjukehuset og heime. Språket er enkelt, lettlest. Også dei aller yngste barna vil kunne ha nytte av og forstå innhaldet. Innimellom kunne nok teksten ha vore stramma litt opp. Tjukt, godt papir gjer at boka kan lesast igjen og igjen og igjen.

Anne Marie Handeland har klart å få fram mange av dei viktigaste tema som har noko å seie for barn som pårørande ved kreft. Denne pappaen har håp om å bli frisk. Nokre av dei barna som les denne boka, vil ikkje ha same rom for håp. Kanskje trengs det ei bok til desse ungane også.
I siste delen har kreftsjukepleiar Ragnhild Stangeland summert opp råd til foreldra. Alderstilpassa informasjon er vesentleg for at barnet skal meistre eige liv i perioden der far eller mor er sjuk. Råda synes å vere relevante og godt oppdaterte. Kanskje kan dei også vere eit utgangspunkt for samtale mellom kontaktsjukepleiar og pasient/pårørande.

Dei viktigaste reaksjonane hos barn når sjukdom rammer, er lista opp og dels forklarte. Eg saknar nokre ord om parentifisering - barn som tek på seg meir ansvar enn dei burde i ei sårbar tid.

Dette er ei lita, men solid bruksbok. Ho gjev eit godt utgangspunkt for dei vaksne til å meistre den vanskelege samtalen med barna.

Dei siste sidene gjev plass til å teikne eller setje inn eigne bilete. Det opnar opp for at boka kan følgje barnet og familien gjennom sjukdomen, og bli eit viktig minne å hente fram når dagane er blitt betre igjen.

Liv Reidun Henriksen Hansen

Barne- og ungdomspsykiatrisk poliklinikk Helse Fonna

Haugesund

\section{Solid om cytostatika}

Dahl O, Lehne G, Baksaas I et al, red. Medikamentell kreftbehandling

Cytostatikaboken. 7. utg. 495 s, tab, ill. Oslo: Farmakologisk institutt, Det medisinske fakultet, Universitetet i Oslo, 2009. Pris NOK 350 ISBN 978-82-9923312-5

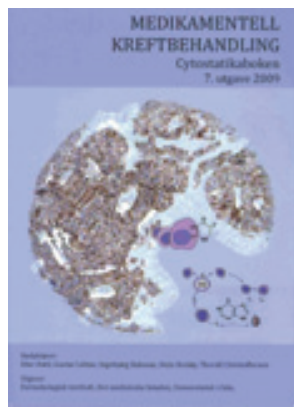

«Cytostatikaboken» er endelig kommet i ny utgave! Mye har skjedd siden den forrige trykte utgaven utkom i 1999; både $\mathrm{i}$ form av ny kunnskap, nye medikamenter, nye behandlingsprinsipper og nye terapianbefalinger. Målgruppen er først og fremst helsepersonell, og målsettingen er å gi en praktisk veiledning og bakgrunn for klinisk bruk av medikamenter mot kreft, hvilket den i stor grad oppfyller.

Innledningsvis gis en kort og oversiktlig innføring i basal cellebiologi og farmakologi. Det er et prisverdig forsøk på å formidle denne kompleksiteten på en forståelig måte. Kunnskap om dette er nødvendig for å kunne forstå

virkningsmekanismene til de enkelte medikamenter, spesielt de nye og såkalte målrettede kreft-midler som er kommet til i løpet av de senere år. Som i tidligere utgaver, 
foreligger en systematisk omtale av de medikamenter som er i bruk; farmakologiske egenskaper, anvendelsesområder, bivirkninger, interaksjoner etc. Gjeldende terapianbefalinger innen de ulike diagnosegrupper og grunnlaget for disse, er omtalt i egne kapitler. Forfatterne tar også i ulike sammenhenger for seg viktige og vanskelige avveiningene rundt når og hvem man skal tilby behandling, rundt livskvalitet og når man bør avslutte eller endre en behandling. Det er ingen detaljerte beskrivelser av administrasjon og dosering av cytostatikakurer, siden dette nå finnes tilgjengelig på nettet i Nasjonalt register for medikamentell kreftbehandling (1). Det er egne kapitler om behandling av smerter og kvalme, metabolske forstyrrelser som hyperkalsemi og tumorlyse, infeksjoner og ernæring. Etter hvert kapittel finnes fyldige litteratur- og referanselister.

Jeg er imponert over hvor mange aspekter ved behandling av kreftsykdom som er tatt med. Men jeg savner noen helseøkonomiske og samfunnsmessige betraktninger rundt moderne og til dels kostbar og ressurskrevende kreftbehandling. Dette er også faktorer som ligger til grunn for nasjonale anbefalinger og retningslinjer. Det er et følsomt område, men ikke desto mindre viktig. Spesielt når vi vet at det foreligger tydelige geografiske forskjeller innen vårt land, både når det gjelder tilbud og resultater av kreftbehandling.

Boken bør ha sin selvfølgelige plass $i$ alle avdelinger og poliklinikker der man behandler eller er i kontakt med kreftpasienter; først og fremst onkologiske, men også ulike kirurgiske og medisinske avdelinger og i allmennpraksis. Den er blitt vesentlig større, men har beholdt sitt paperbackformat, og den synes å være av så god kvalitet at den kan tåle å brukes så ofte som den fortjener. Den vil også foreligge i en nettutgave på Helsebibiotekets sider (2), og med lenker til relevante og oppdaterte databaser.

\section{Åse Skår}

Kreft- og kirurgisk divisjon

Oslo universitetssykehus, Ullevål

\section{Litteratur \\ 1. Nasjonalt register for medikamentell kreftbe- handling. http://oncolex.no (24.2.2010). 2. Helsebiblioteket. www. helsebiblioteket.no (24.2.2010).}

\section{Ortopedisk metodebok - nesten bra}

Andreassen GS, red.

Metodebok for Ortopedisk Senter

202 s, ill. Trondheim: Legeforlaget, 2009.

Pris NOK 300

ISBN 978-82-92934-04-3

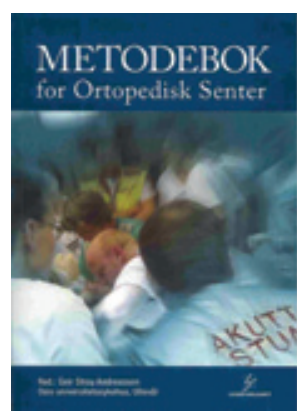

Det er drøyt 26 år siden den første norske metodeboken i ortopedisk kirurgi ble til ved Haukeland sykehus. Siden har de fleste store avdelingene laget $\sin$ versjon. Ortopedisk Senter ved Oslo universitets-

sykehus, Ullevål presenterer nå sin andre trykte utgave.

En metodebok skiller seg fra en lærebok ved at metodeboken kun skal beskrive de metoder avdelingen har valgt å anvende i sin diagnostikk og behandling. Alternativer som avdelingen ikke har valgt, omtales ikke og det er meningen at bokens anbefalinger skal følges i den daglige pasientbehandlingen. En metodebok henvender seg først og fremst til avdelingens egne leger og i noen grad til annet behandlingspersonell. Men det er også naturlig og riktig at avdelinger innen regionen følger anbefalingene i regionsykehusets metodebok. På den måten blir pasienthåndteringen forutsigbar og kontrollerbar.

Med et par små unntak, har den foreliggende boken en særdeles grei og oversiktlig oppbygning. De aller fleste viktige ortopediske problemer er omtalt, og hvert kapittel er i utgangspunktet systematisk bygd over samme lest. Undertitlene følger samme systematikk i de fleste kapitlene.

I bokens første del blir «Generelle forhold» omtalt på en utmerket måte. Her beskrives bl.a. generelle rutiner, beredskapsplan, hygiene, rutiner ved øyeblikkelig hjelp-overflytting, ivaretaking av pasienter med rusproblemer, forebygging av tromboembolisk sykdom og andre generelle rutiner.

I den spesielle delen omtales de fleste vanlige og en del mindre vanlige, ortopediske tilstander og skader. Også denne delen er systematisk oppbygd. Men her er det en del mangler. Klassifisering og diagnostikk er for det meste omtalt på en god, om enn kortfattet måte. Mer ujevnt er det når man kommer til behandling. I noen kapitler beskrives f.eks. anbefalt operasjonsmetode på en grei måte, mens i andre blir ikke operasjonsteknikken omtalt i det hele tatt, og heller ikke oppgis det referanse - slik at leseren kan finne metoden andre steder. Som nevnt er en viktig hensikt med en metodebok nettopp å standardisere avdelingens behandling. Derfor er dette en alvorlig svakhet.

I mange kapitler savnes også en angivelse av prognose og komplikasjoner.

Det er en del, ikke mange, illustrasjoner, for det meste tegninger. Disse er enkle og illustrerer det aktuelle problemet godt.

Siden dette er en bok til daglig og praktisk bruk, er det viktig at den har et hendig format slik at den er brukervennlig og får plass i lommen på den hvite frakken. Dette er ifølge forordet en av grunnene til at den er kortfattet. Men den hadde nok fått plass $i$ frakkelommen selv om noen viktige punkter hadde vært noe bredere omtalt. Min konklusjon blir at dette er en bra bok med et betydelig forbedringspotensial.

\section{Norvald Langeland}

Norsk pasientskadeerstatning

Oslo

\section{Demensguide oppdatert og i ny design}

\section{Solheim K.}

\section{Demensguide}

Holdninger og handlinger i demensomsorgen. 2. utg. 416 s, tab, ill. Oslo: Universitetsforlaget, 2009. Pris NOK 399

ISBN 978-82-15-01564-4

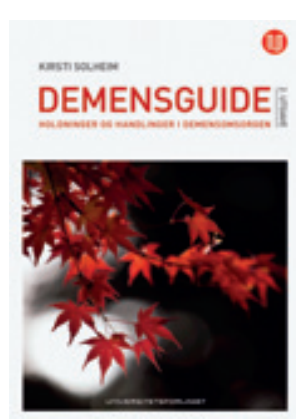

Målgruppen er pleie- og omsorgspersonell på sykehjem, dagsenter og i hjemmebaserte tjenester. Boken er primært ment å skulle brukes i kommunehelsetje nesten, men vil også være et supplement for stu-

denter innen helsefag i grunn- og videreutdanningen. Stoffet er presentert i tre deler. Del 1 er en oversikt over hovedtemaer og legger grunnlag for del 2, som er inndelt alfabetisk etter aktuelle behov og problemstillinger, og som er ment som et oppslagsverk. Del 3 er en bilagsdel, som inneholder vedlegg. Språket et enkelt og forståelig med få fremmeduttrykk. Designen er ny og tidsriktig. De «grønne bladene» som er en rød tråd gjennom teksten, er illustrert med røde blader på omslaget. Det er sparsomt med illustrasjoner, noe annet kunne man heller ikke er forventet.

Del 1, som er mest relevant for leger, bærer preg av at boken kun har gjennomgått en oppgradering og ingen revisjon. Det har skjedd mye med tanke på inndelingen og etiologien til demenssykdommene, og dette kunne med fordel vært bedre oppdatert. 